\title{
THE ECONOMIC SECURITY OF HIGHER EDUCATION INSTITUTIONS FROM THE PERSPECTIVE OF INTERNATIONAL COMPETITION
}

\author{
Alla Kasych1', Svitlana Breus², Yevheniia Khaustova ${ }^{3}$
}

\begin{abstract}
The purpose of the article is to develop a methodological approach towards assessing the economic security of institutions of higher education. Methodology. There has been generalized the experience of foreign universities in terms of providing high standards of educational and research process in the context of ensuring their economic security in modern conditions. The study has been conducted on the comparison of aggregate indicators of the economic security of HEls based on the results of factor analysis (the method of the main components). The output data are formed taking into account the main approaches to constructing a balanced system of indicators based on the results of cluster analysis. The integral indicators of economic security of HEls and integral indicators of economic security in general have been calculated based on the values of factor loadings and weighting coefficients of indicators for each group. Results. The system of performance indicators of the world leading universities has been formed and the key factors of economic security of foreign universities have been identified taking into account the generalized experience of foreign universities. The developed methodological approach to the assessment is universal and provides opportunities for developing measures to improve the level of economic security of institutions of higher education. Studies have shown that the economic security of economic entities is not least determined by the management efficiency of intellectual resources. Practical implications. The calculated level of HEl economic security is an indicator not only for protecting it from threats but also for the causal link between socio-economic development of the state, its economic potential and the level of higher education. Value/originality. The holistic scientific and practical study has been carried out in the article taking into account the interconnection of higher education and economic security of institutions of higher education and a methodical approach to the evaluation of the economic security of HEls has been developed. The above stipulates the necessity of developing a methodological approach to assessing the risks to the economic security of institutions of higher education on the basis of possible threats to their activities.
\end{abstract}

Key words: balanced indicators system, development and personnel training indicators, factor analysis, aggregate indicators, economic security of institutions of higher education.

JEL Classification: C38, C43, 125

\section{Introduction}

Institutions of higher education play a leading role in training highly skilled professionals to meet the labour market needs, which is actualized in the context of globalization and the transition to an economy of knowledge. At the same time, ensuring their economic security plays an important role both in the development of the state and society as a whole because the economic security of institutions of higher education is the HEIs protection from the negative influence of a number of factors from the external and internal environment in terms of efficiency of resources available to protect against their activities' threats. Thus, the level of economic security of institutions of higher education is an indicator not only of protecting them from threats but also of the causal link between socio-economic development of the state, its economic potential, and the level of higher education.

Universities in developed countries are not just educational institutions but are at the forefront of the society, science and culture development, and therefore, their development forms not only their security but also

\footnotetext{
Corresponding author:

${ }^{1}$ Kyiv National University of Technologies and Design, Ukraine.

E-mail: kasich.alla@gmail.com

${ }^{2}$ Kyiv National University of Technologies and Design, Ukraine.

E-mail: breus.svitlana@gmail.com

${ }^{3}$ Kyiv National University of Technologies and Design, Ukraine.

E-mail: g.haystova@gmail.com
} 
is the basis of the whole country economic security. That is why, in the process of university development strategy, there are consultations with the community, which allow taking into account the requirements of the public, local authorities, strategic guidelines for the state development. For example, the University of Washington mission is to create a unique community of teachers and students who are capable of large-scale research and seek to improve the lives and livelihoods of students in the region, the country and the world (Washington University Consolidated Financial Statements). An even more ambitious mission is the one of Cambridge University, which is to contribute to the development of society through the achievement of teaching, learning, and research at the highest international level (University of Cambridge Annual Report, 2016).

Leading universities in the educational services market clearly understand that their credibility and future economic security depend on the educational process quality and scientific achievements level. Accordingly, one should dwell on the foreign universities experience generalization in terms of ensuring the high standards of educational and research process. The main indicators characterizing the world leading universities activities are presented in Table 1.

Key factors of the economic security of foreign universities are the following: personnel, material and technical base, financial capabilities, organizational innovations, etc.

Personnel, its reputation, qualification, initiative, ability to apply innovative approaches in professional activity determine the quality of teaching.

The effectiveness of scientific research is determined not only by the University's revenues from commercialization but also by the number of firms founded on the basis of university scientists' intellectual property. Publications by lecturers and university students and their presentation in Scopus and ThomsonReuters bases are important. The Hirsch Teacher's Index is used not only in making managerial decisions about career growth but also in making agreements.

Material and technical base. Only a high-quality material and technical base will enable the university to achieve excellence in teaching, research and support of the world image in the future. This is the main approach when determining the amount of funding for these goals. Most of the leading universities have their own campuses. Accordingly, universities develop a campus development program that seeks to improve not only the learning process conditions but also conditions for the comprehensive development of students and their living conditions through the transport systems and infrastructure upgrading. Creating, for example, nanoscale hubs, business schools, incubators - all these investments in the development of the material and technical base are the ability of students to become active participants in the already innovative processes, which significantly increases the image of the university and, therefore, its economic security.

Financial capabilities. "If you see any economy that is not doing well, find out what is spent on education" (Ola, 1998; Omotor, 2004). The basis of universities economic security in modern conditions is their financial capabilities, which have significant differences in different countries. So, leading universities have annual revenues of $\$ 2-9$ billion (Table 1) against the background of total annual education expenditure in Ukraine, which is about 6\% of GDP and does not exceed $\$ 6$ billion.

Table 1

World leading universities activities indicators

\begin{tabular}{|c|c|c|c|c|c|c|c|c|}
\hline & & & & & & & & $\begin{array}{l}\text { Charles } \\
\text { University }\end{array}$ \\
\hline & & 2015 & 2016 & 2015 & 2016 & 2015 & 2016 & 2016 \\
\hline 1. & $\begin{array}{l}\text { Number of students, bachelors, } \\
\text { masters, } \\
\text { PhD }\end{array}$ & $\begin{array}{l}22348 \\
11703 \\
10645 \\
\end{array}$ & $\begin{array}{l}22602 \\
11603 \\
10999 \\
\end{array}$ & $\begin{array}{c}16190 \\
6994 \\
9196 \\
\end{array}$ & $\begin{array}{c}16336 \\
7032 \\
9304 \\
\end{array}$ & $\begin{array}{c}21430 \\
7240 \\
14190 \\
\end{array}$ & $\begin{array}{c}21790 \\
7330 \\
14460 \\
\end{array}$ & $\begin{array}{l}51438 \\
18896 \\
32542 \\
\end{array}$ \\
\hline 2. & $\begin{array}{l}\text { Number of teaching } \\
\text { staff, professors, } \\
\text { researchers }\end{array}$ & $\begin{array}{l}1680 \\
4501\end{array}$ & $\begin{array}{l}1747 \\
4634\end{array}$ & 2153 & 2180 & 1514 & 1631 & 4653 \\
\hline 3. & Revenues, US dollars, millions & 1982 & 1718 & 9051 & 9797 & 4525 & 4776 & 393 \\
\hline 4. & Expenditures, US dollars, millions & 1714 & 1737 & 8351 & 9307 & 4463 & 4700 & 391 \\
\hline 5. & Net profit, US dollars, millions & 268 & -19 & 700 & 490 & 62 & 76 & 2 \\
\hline 6. & Net assets, US dollars, millions & 3692 & 3913 & 30434 & 31719 & 45402 & 43397 & 601 (assets) \\
\hline 7. & Fixed assets, US dollars, millions & 1640 & 1728 & 7797 & 9000 & 6184 & 6529 & - \\
\hline 8. & $\begin{array}{l}\text { Average cost of a bachelor's } \\
\text { degree, US dollars }\end{array}$ & - & - & 44184 & 45729 & - & - & - \\
\hline
\end{tabular}

Source: Facts and Figures Charles University, Financial report Harvard University 2016, Stanford University Annual Report 2016, The University of Oxford Financial Statements 2015/16 
Supporting financial sufficiency for the university means the ability to continue to attract and retain the best staff, as well as provide research and teaching materials that are consistent with the world's leading universities positions.

Taking into account all the above, it should be noted that one of the major threats to higher education in Ukraine is, among other things, the spread of globalization processes in the educational sector and the expansion of the international education market. The experience of foreign universities, in particular in the context of improving the educational service quality, is outlined in works (Banjong \& Olson, 2016; Ding, 2016; Nicholls, 2018).

The generalization of the results of the international education market study, conducted on the basis of various statistical information, suggests that the market of international education is rather dynamic and opens opportunities for competitive educational systems. In total, over the past 20 years, the number of mobile foreign students has increased by almost 3 times from 1.7 million in 1996 to 4.7 million in 2017. Experts predict that the number of students to study abroad should reach 8 million in 2025 (Figure 1).

According to the experts (GLOBAL: International students: a $\$ 100$ billion business? 2009) who have tried to assess this global market segment, the potential value will already be $\$ 100$ billion in the near future. This suggests that education is turning into a business, which, in the case of international attractiveness, provides significant financial resources to the country's economy. Accordingly, the provision of qualitative educational services allows the country to attract sufficient financial resources to the economy. For example, in 2014, international students have invested in the US economy nearly $\$ 27$ billion (Banjong \& Olson, 2016).

Taking into account the foregoing it should be noted that in modern conditions, the relationship between higher education and economic security is observed. The study of the economic security level has been conducted on the basis of data from the Ukrainian HEIs, which are typical representatives of the educational services market.

The destructive processes in the Ukrainian economy are reflected in the activities of higher education institutions (HEI) as elements of the social and economic system. The negative trends from the demographic crisis and external migration were accompanied by social and economic consequences of external aggression, which did not go beyond higher education. Moving education institutions from the temporarily occupied territories was an objectively necessary measure, which had significant negative consequences: total loss and the need to restore the material and technical base, reduction of a half of academic staff (AS) and students, as well as the loss of partially recovering intellectual resources (methodological support of education processes, software products, information bases, image and business relations), etc.

Taking into account the importance of HEIs for the development of the country's social and economic system, determining their economic security, it is expedient to consider the possibility of reproducing their intellectual potential of the nation, which has a positive impact on the economic security of the state as a whole. It is important to further develop universal methodological approaches to assessing the economic security of the HEI, in particular, those moved from temporarily occupied territories.

\section{Literature review}

Scientists also consider the role of education in the formation of national innovation systems (Kasych \& Vochozka, 2017), and foreign experience, in particular, as for the sources of funding HEI activities (Kasych \& Tsygan, 2013) has been studied in a certain way. The relationship between education and economic security and the ability of education to influence the economic vulnerability level of any country are highlighted in the

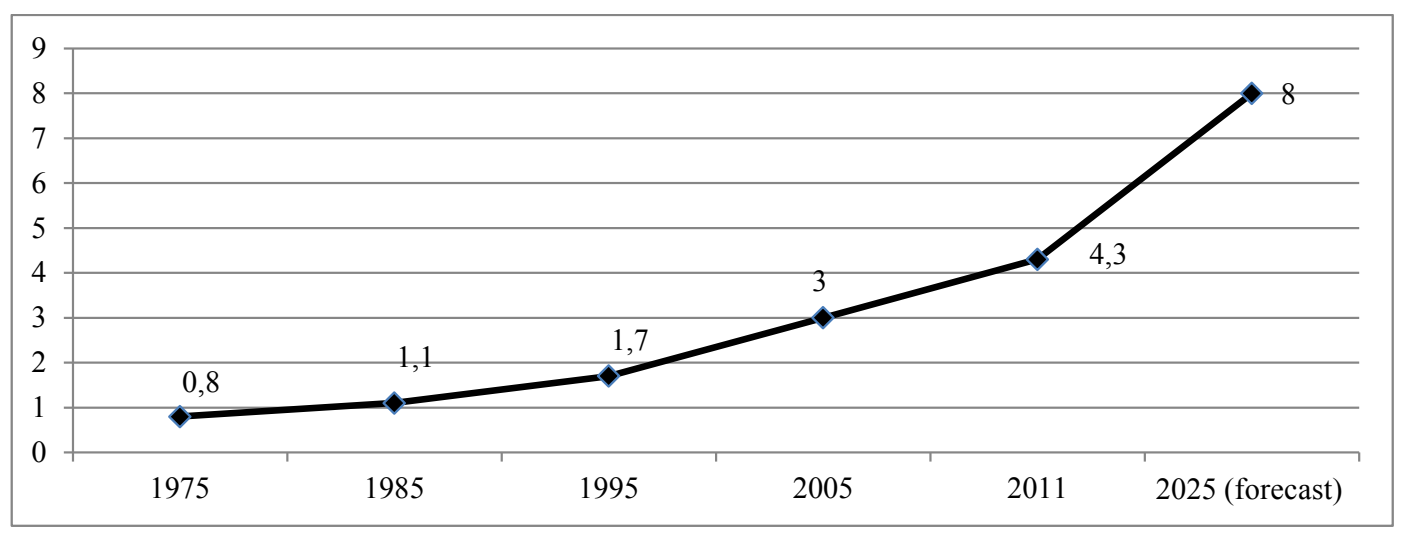

Figure 1. The number of students studying abroad

Source: compiled according to the data (Number of international students) 
work (Munteanu \& Munteanu, 2015). The research (Kendiukhov, 2008) shows that the economic security of an economic entity today is largely determined by the efficiency of intellectual capital management. Therefore, the strengthening of the intellectual component in the activities of educational institutions of Ukraine (Illiashenko, 2011, Sardak, 2016, Kasych \& Vochozka, 2017) requires an appropriate addition and systematization of factors that should be taken into account in the formation of indicators for estimating economic security.

Despite the consideration of issues related to the estimation of the economic security of higher education institutions, it is necessary to expand the database of empirical studies, in particular, taking into account the results of relevant studies on the institutions' economic security in the condition of external aggression. The research on the comparison of aggregate indicators of economic security of higher education institutions (moved from temporarily occupied territories) based on the results of factor analysis (by principal component method).

\section{Purpose and methodology of the article}

The purpose of the article is to develop a methodological approach to assessing the economic security of institutions of higher education. Conducting research on the comparison of aggregate indicators of HEIs economic security based on the results of factor analysis (by principal components method). The output data have been formed on a balanced system of indicators by the results of cluster analysis. Based on the values of factor loadings and weight coefficients of indicators for each group, integral indicators of individual universities economic security have been calculated.

In order to systematize the estimation indicators for HEI economic security, there have been taken into account the balanced indicator system (the Balanced Scorecard - BSC) (Kaplan \& Norton, 2005) adapted to the needs of institutions of higher education (Breus, Khaustova \& Denysenko, 2017; Breus, 2018). The output data (indicators) of HEI have been formed according to the following groups: "Finance", "Students", "Internal processes", "Academic staff development and training" subdividing them into stimulant indicators and disincentive indicators.

At the same time, stimulant indicators (contributing to raising the level of economic security) include the following:

- the group "Finance": the correlation between the licensed volume of acceptance to studies and the volume of the public procurement for the 1st year of studying according to the training programs of bachelors and masters; the average number of academic staff per one economic contract and scientific research, financed by budget funds;
- the group "Students": the correlation between the number of students and the number of academic staff, the correlation between the number of acceptance to studies to the 1st year of full-time education and the number of titles of accredited specialties for bachelor's and master's programs;

- the group "Internal processes": percentage of fulltime academic staff having a doctor's degree/degree of candidate of sciences and the total number of full-time academic staff, the correlation between the total book funds and the number of students;

- the group "Academic staff development and training": the level of academic staff creative and innovative performance, the coefficient of academic staff scientific recognition.

The disincentive indicators (contributing to lowering the level of economic security) include the following indicators;

- the group "Finance": the correlation between the licensed volume of acceptance to studies and the volume of the public procurement for the 1st year of studying according to the training programs of bachelors and masters;

- the group "Students": the correlation between the licensed volume of acceptance to studies and the number of applicants to the 1st year of full-time study programs of bachelors and masters, the correlation between the number of students in full-time and parttime studies;

- the group "Internal processes": the correlation between the number of titles of accredited specialties to the programs of bachelor/masters training and the number of departments;

- the group "Academic staff development and training": the coefficient of the necessity of computing technology and access to network resources.

Using the statistic software Statistica and factor analysis (method of the principal components), out of the output data of every HEI there have been outlined principal components (factor 1 and factor 2), at the same time:

- for all institutions, the indicators of the "Internal processes" group are merged only into factor 1 , which indicates the expediency of reducing their number, in particular, by introducing a common indicator percentage of full-time academic staff having a doctor's degree/degree of candidate of sciences or being a professor or associate professor and the total number of full-time academic staff;

- for all institutions, the indicators of the "Students" group immediately form factors 1 and 2, except for the correlation between the number of students in full-time and part-time studies, which is included only in factor 1. It indicates the relative continuity of this correlation and the possibility of using it as a universal indicator in assessing the economic security of education institutions; 
- the indicator of the "Finance" group - the correlation between the licensed volume of acceptance to studies and the volume of the public procurement for the 1st year of studying has a negative value of factor loadings. It corresponds to the essence of this indicator, that is, an increase in the level of budget financing against the background of reducing the number of educational contracts and is a negative factor in ensuring the economic security of the educational institution.

According to the factor analysis results of the input data, there were determined factor loadings, on the basis of which coefficients of each indicator for each group of each higher institution were calculated (the product of the maximum loading for each indicator and the share of the total dispersion is calculated, multiplied by the total sum of the outputs of indicators for each group, and then the weighting factor of each indicator for each group for each grade is calculated as the ratio of the product for each indicator and the total amount of products) using the recommendations of National Institute for Strategic Studies (2013), Ministry of Economic Development and Trade of Ukraine (2013), State Statistics Committee of Ukraine (2003).

Normalized values of the stimulant indicators and destimulant indicators, as well as their weighting factors, become the basis for calculating integral indicators of economic security for each group of a separate high institution and an integral indicator of economic safety with the use of additive convolution (Ministry of Economic Development and Trade of Ukraine (2013), State Statistics Committee of Ukraine (2003) (formula 1).

$$
I_{m}=\sum_{i=1}^{n} d_{i} \times y_{i}
$$

where $I_{m}$ is an aggregate indicator (integral indicator for the group of indicators) / sub-index of the $\mathrm{m}^{\text {th }}$ group of indicators of HEI economic security, $m=(1,2,3,4)$;

$d_{i}$ is the weight of the indicator, which determines the degree of contribution of the $i^{\text {th }}$ indicator to the integral index of the component (groups of indicators) of HEI economic security;

$y_{i}$ is a normalized value of the $i^{\text {th }}$ indicator; $n$ is the number of indicators used to evaluate the $i^{\text {th }}$ indicator in the aggregated indicator (integral indicator in the group of indicators) / sub-index of the $m^{\text {th }}$ group of indicators of HEI economic security;

$$
\sum d_{i}=1 ; 0 \leq d_{i} ; y_{i} \leq 1 \text {. }
$$

The information about an integral indicator of economic security in general for each higher institution with the use of additive convolution (Ministry of Economic Development and Trade of Ukraine (2013), State Statistics Committee of Ukraine (2003) has been carried out by the formula 2 .

$$
I I_{\text {ESHEI }}=\sum_{m} d_{m} \times I_{m} \text {, }
$$

where $I I_{E S H E I}$ is an integral indicator of HEI economic security; $d_{m}$ is weight coefficient, which determines the degree of contribution of the index/subindex of the $m^{\text {th }}$ group of economic security to the integral index of economic security of institutions of higher education:

$$
\sum d_{m}=1 ; 0 \leq d_{m} ;
$$

$I_{m}$ is an aggregate index/subindex of the $m^{\text {th }}$ group of economic security, where $\mathrm{m}=(1,2,3,4)$.

\section{The main material of the research \\ Clustering HEIs according to the indices of the domestic ranking}

In order to study the dynamics of indicators of economic security, there has been carried out a selection of HEIs from those moved from temporarily occupied territories of Ukraine. It has been based on the assumption that institutions with better rating positions have a performance dynamics that reflects more fully the general tendencies in changes in the economic security of all HEIs moved from temporarily occupied territories.

The cluster analysis of HEIs has been conducted using the software Statistica and the $k$-medium method. After normalizing the initial data (indexes of the integral indicator in the Ranking of HEIs "TOP-200 Ukraine"), HEIs were assigned to clusters at a minimum Euclidean distance to the centre of gravity of such a cluster. The configuration of the obtained clusters and distances to the centre of gravity are given in Table 2.

According to the received data, the first cluster includes HEIs that either have relatively retained their positions in the rating and continue to occupy higher positions in comparison with other HEIs displaced from temporarily occupied territories, such as: Donetsk National Technical University (DonNTU); Vasyl Stus Donetsk National University (Vasyl Stus DonNU); Volodymyr Dahl East Ukrainian National University (V. Dahl EUNU); Luhansk Taras Shevchenko National University (T. Shevchenko LNU).

The second cluster includes only one HEI, which has the growth of the academic potential index, at the same time the decrease of innovative activity index and international recognition index; as a result, this university has considerably worsened its rating positions. The third cluster includes such HEIs that show a decrease in all indices and they occupy lower-ranking positions compared with HEIs in the clusters 1 and 2.

\section{Results of the integrated assessment of the safety level of HEIs}

The results of calculating aggregated economic security indicators by groups are presented in Table 3 .

According to Table 3, a factor analysis of integral indicators by groups (by principal component method) was conducted, which resulted in factor loadings before and after the rotation procedure (quartimax normalized) for each group for a specific HIE (the value of the most significant indicators is highlighted) (Table 4). 
Table 2

The configuration of each cluster and the distance to the centre of gravity

\begin{tabular}{|c|c|c|c|c|c|c|c|}
\hline $\begin{array}{l}\text { Cluster, } \\
\text { distance }\end{array}$ & \multicolumn{7}{|c|}{ Observations (Institution of higher education) } \\
\hline Cluster 1 & \multicolumn{2}{|c|}{$\begin{array}{c}\text { C_1 } \\
\text { Donetsk National Technical } \\
\text { University (DonNTU) }\end{array}$} & \multicolumn{2}{|c|}{$\begin{array}{c}\text { C_2 } \\
\text { Vasyl Stus Donetsk National } \\
\text { University (Vasyl Stus } \\
\text { DonNU) }\end{array}$} & \multicolumn{2}{|c|}{$\begin{array}{c}\text { C_3 } \\
\text { Volodymyr Dahl East } \\
\text { Ukrainian National } \\
\text { University (V. Dahl EUNU) }\end{array}$} & $\begin{array}{c}\text { C_4 } \\
\text { Luhansk Taras } \\
\text { Shevchenko National } \\
\text { University } \\
\text { (T. Shevchenko LNU) }\end{array}$ \\
\hline Distance & \multicolumn{2}{|c|}{0.479480} & \multicolumn{2}{|c|}{0.386527} & \multicolumn{2}{|c|}{0.606224} & 1.004392 \\
\hline Cluster 2 & \multicolumn{7}{|c|}{ C_6 (Donetsk National Medical University) DonNMU } \\
\hline Distance & \multicolumn{7}{|c|}{0.000000} \\
\hline Cluster 3 & $\begin{array}{c}\text { C_5 } \\
\text { Donetsk National } \\
\text { University of } \\
\text { Economics and } \\
\text { Trade named } \\
\text { after Mykhailo } \\
\text { Tugan-Baranovsky } \\
\text { (DonNUET } \\
\text { named after } \\
\text { M. Tugan- } \\
\text { Baranovsky) }\end{array}$ & $\begin{array}{c}\text { C_7 } \\
\text { (Donetsk State } \\
\text { University of } \\
\text { Management) } \\
\text { DSUM }\end{array}$ & $\begin{array}{c}\text { C_ } 8 \\
\text { V.I. } \\
\text { Vernadsky } \\
\text { Taurida } \\
\text { National } \\
\text { University } \\
\text { (V.I. } \\
\text { Vernadsky } \\
\text { TNU) }\end{array}$ & $\begin{array}{c}\text { C_9 } \\
\text { Donbas State } \\
\text { Technical } \\
\text { University } \\
\text { (DonSTU) }\end{array}$ & $\begin{array}{c}\text { C_10 } \\
\text { Luhansk } \\
\text { State Medical } \\
\text { University } \\
\text { (SI LSMU) }\end{array}$ & $\begin{array}{c}\text { C_11 } \\
\text { Luhansk } \\
\text { National } \\
\text { Agrarian } \\
\text { University } \\
\text { (LNAU) }\end{array}$ & $\begin{array}{c}\text { C_12 } \\
\text { Donbas National } \\
\text { Academy of Civil } \\
\text { Engineering and } \\
\text { Architecture } \\
\text { (DonNACEA) }\end{array}$ \\
\hline Distance & 0.596213 & 0.366310 & 0.286135 & 0.206771 & 0.482595 & 0.365469 & 0.563731 \\
\hline
\end{tabular}

Table 3

Integral indicators (aggregated indicators) of economic security by groups

\begin{tabular}{|c|c|c|c|c|}
\hline \multirow[b]{2}{*}{ Years } & \multicolumn{4}{|c|}{ Groups } \\
\hline & "Finance" & "Students" & "Internal processes" & $\begin{array}{c}\text { "Development and } \\
\text { training of academic staff" }\end{array}$ \\
\hline \multicolumn{5}{|c|}{ DonNTU } \\
\hline 2014 & 0,9925 & 0,6853 & 0,0 & 0,5038 \\
\hline 2015 & 0,5339 & 0,4151 & 0,4703 & 0,3082 \\
\hline 2016 & 0,0326 & 0,3534 & 1,0 & 0,5219 \\
\hline \multicolumn{5}{|c|}{ Vasyl Stus DonNU } \\
\hline 2014 & 0,8344 & 0,2910 & 0,6467 & 0,7077 \\
\hline 2015 & 0,0 & 0,2554 & 1,0 & 0,3131 \\
\hline 2016 & 0,5475 & 1,0 & 0,1805 & 0,4227 \\
\hline \multicolumn{5}{|c|}{ V. Dahl EUNU } \\
\hline 2014 & 0,6659 & 0,9565 & 0,2498 & 0,0621 \\
\hline 2015 & 0,3261 & 0,3820 & 0,4071 & 0,3928 \\
\hline 2016 & 0,4690 & 0,2015 & 0,7502 & 1,0 \\
\hline \multicolumn{5}{|c|}{ T. Shevchenko LNU } \\
\hline 2014 & 0,3351 & 0,8475 & 0,4821 & 0,0080 \\
\hline 2015 & 0,1202 & 0,1615 & 0,3965 & 0,9341 \\
\hline 2016 & 0,8802 & 0,3475 & 0,7244 & 0,5102 \\
\hline
\end{tabular}

Based on formula 2 and according to Tables 2 and 3, there have been done the calculations of the integral indicator of HEI economic security by years (Table 5).

The range of inherent values of HEI economic security levels is enshrined in the Guidelines of Ministry of Economic Development and Trade of Ukraine (2013), according to which the level is equal to 0 is absolutely dangerous; the level in the range from 0 to 0.2 is critical; from 0.2 to 0.4 is dangerous; from 0.4 to 0.6 is unsatisfactory; from 0.6 to 0.8 is satisfactory; from 0.8 to 1 is optimal.
The data in Table 5 show the increase of the level of economic security for V. Dahl EUNU and T. Shevchenko LNU to the satisfactory level during 2014-2016. The level of economic security of DonNTU during 2014-2016 has remained at the unsatisfactory level, while the level of economic security of Vasyl Stus DonNU has declined from satisfactory to unsatisfactory level. The deterioration of their economic security is explained by the fact that after having lost a significant part of its potential, these HEIs as the most powerful does not have enough resources for its relatively quick recovery, 
Vol. 4, No. 5, 2018

Baltic Journal of Economic Studies

Table 4

Factor loadings before and after rotation

\begin{tabular}{|c|c|c|c|c|}
\hline \multirow{2}{*}{ Groups } & \multicolumn{2}{|c|}{ Factor loadings (before rotation) } & \multicolumn{2}{|c|}{ Factor loadings (after rotation) } \\
\hline & Factor 1 & Factor 2 & Factor 1 & Factor 2 \\
\hline \multicolumn{5}{|l|}{ DonNTU } \\
\hline "Finance" & $-0,9918$ & $-0,1278$ & 0,9943 & $-0,1064$ \\
\hline "Students" & $-0,9700$ & 0,2430 & 0,9646 & 0,2638 \\
\hline "Internal processes" & 0,9907 & 0,1363 & $-0,9934$ & 0,1150 \\
\hline "Development and training of academic staff" & $-0,0260$ & 0,9997 & 0,0045 & 1,0 \\
\hline Total dispersion & 2,9067 & 1,0933 & 2,9059 & 1,0941 \\
\hline The share of total dispersion & 0,7267 & 0,2733 & 0,7265 & 0,2735 \\
\hline \multicolumn{5}{|l|}{ Vasyl Stus DonNU } \\
\hline "Finance" & 0,8862 & 0,4633 & $-0,3161$ & $-0,9487$ \\
\hline "Students" & 0,6462 & $-0,7632$ & $-0,9949$ & 0,1006 \\
\hline "Internal processes" & $-0,8932$ & 0,4497 & 0,9550 & 0,2965 \\
\hline "Development and training of academic staff" & 0,6127 & 0,7903 & 0,1078 & $-0,9942$ \\
\hline Total dispersion & 2,3760 & 1,6240 & 2,0135 & 1,9865 \\
\hline The share of total dispersion & 0,5940 & 0,4060 & 0,5034 & 0,4966 \\
\hline \multicolumn{5}{|l|}{ V. Dahl EUNU } \\
\hline "Finance" & 0,6962 & $-0,7179$ & $-0,4041$ & 0,9147 \\
\hline "Students" & 0,9905 & $-0,1373$ & $-0,8815$ & 0,4721 \\
\hline "Internal processes" & $-0,9337$ & $-0,3580$ & 0,9999 & 0,0121 \\
\hline "Development and training of academic staff" & $-0,9481$ & $-0,3179$ & 0,9995 & $-0,0304$ \\
\hline Total dispersion & 3,2366 & 0,7634 & 2,9394 & 1,0606 \\
\hline The share of total dispersion & 0,8091 & 0,1909 & 0,7348 & 0,2652 \\
\hline \multicolumn{5}{|l|}{ T. Shevchenko LNU } \\
\hline "Finance" & $-0,7843$ & 0,6204 & 0,9979 & 0,0654 \\
\hline "Students" & $-0,6355$ & $-0,7721$ & $-0,0459$ & 0,9989 \\
\hline "Internal processes" & $-0,7695$ & 0,6386 & 0,9991 & 0,042 \\
\hline "Development and training of academic staff» & 0,7823 & 0,6230 & $-0,1629$ & $-0,9866$ \\
\hline Total dispersion & 2,2231 & 1,7769 & 2,0226 & 1,9774 \\
\hline The share of total dispersion & $\mathbf{0 , 5 5 5 8}$ & 0,4442 & $\mathbf{0 , 5 0 5 7}$ & 0,4943 \\
\hline
\end{tabular}

Table 5

The value of integral indicators of institutions' economic security and over the years

(Ranking of institutions of higher education “TOP-200 Ukraine”)

\begin{tabular}{|c|c|c|c|c|}
\hline Years & DonNTU & Vasyl Stus DonNU & V. Dahl EUNU & T. Shevchenko LNU \\
\hline 2014 & $0,5520(20)$ & $0,6161(25)$ & $0,4282(34)$ & $0,4193(33)$ \\
\hline 2015 & $0,4867(23)$ & $0,3921(32)$ & $0,3874(37)$ & $0,3999(49)$ \\
\hline 2016 & $0,4696(25)$ & $0,5416(27)$ & $0,6484(41)$ & $0,6180(64)$ \\
\hline
\end{tabular}

as opposed to V. Dahl EUNU and T. Shevchenko LNU. The latter, despite the lowest level of economic security in 2014, partially offset their losses due to the relative improvement of the intellectual component and the increase in the share of non-budget financing.

\section{Conclusions}

The study of foreign experience in ensuring the development of leading universities allowed, among other things, to highlight the importance of ensuring effective staff management through the selection of HEI scientists and university entrants; development of material and technical base; the expansion of financial capacity, the promotion of professional growth by teachers and students, etc.
Taking into account the generalized experience of foreign universities, a system of performance indicators of the world leading universities has been formed and the key factors of economic security of foreign universities are highlighted. Assessing the economic security of HEIs as elements of the social and economic system, it is expedient to consider the intellectual component. Studies have shown that the economic security of economic entities is not least determined by the management efficiency of intellectual resources. In this regard, it is important to pay attention to the opinion of leading scientists on the HEI management on the expediency of expanding factors in the formation of indicators for estimating their economic security. 
Taking into account the mentioned above, it should be noted that the developed methodological approach can be universal and widespread among all HEIs. Its results can become the basis for the development of targeted measures and for the increase of the economic security level of institutions of higher education. On this ground, the more vulnerable from the point of view of economic security are institutions whose educational and scientific activities require a strong technical basis (laboratories, productions, etc.) with a relatively high level of budget financing. The implementation of this will facilitate the enterprises needs securement to qualified specialists. This in its turn, in the long run, will contribute to raising the level of Ukraine's economic development on the innovation basis, its competitiveness and ensuring the economic security both of HEIs and of the state and national security in general.

Empirical studies concerning the HEI economic security assessment require the development of measures, the realization of which will help to alleviate the negative trends that have accumulated during education in recent years. This can be achieved by increasing the international competitiveness of Ukrainian universities, which requires:

- to develop and implement a strategy for attracting foreign students to study in Ukraine through the improvement of the material and technical base, the provision of competitive educational programs, and teachers' skills improvement;

- to conduct real research on foreign students' needs in different countries and ways to meet them;

- to study foreign universities experience in offering high-quality educational services in the international market.

The mentioned above stipulates the necessity of developing a methodological approach to assessing the risks to the economic security of institutions of higher education on the basis of possible threats to their activities.

\section{References:}

Washington University consolidated financial statements. Retrieved from: https://wustl.edu/about/missionstatement/ (in English)

University of Cambridge annual report 2016. Retrieved from: https://www.cam.ac.uk/annual-report (in English)

Facts and figures Charles University. Retrieved from: http://www.cuni.cz/UKEN-109.html (in English)

Financial report Harvard University 2016. Retrieved from: https://finance.harvard.edu/annual-report (in English) Stanford University annual report 2016. Retrieved from: https://www.ox.ac.uk/sites/files/oxford/field/ (in English) The University of Oxford financial statements 2015/16. Retrieved from: http://www.ox.ac.uk (in English)

Ola, V. (1998). Education in national development. Vanguard Newspaper, August 2, 14 (in English)

Omotor, D. G. (2004). An analysis of Federal Government expenditure in the education sector of Nigeria: implications for national development. Journal of Social Sciences, 9(2), 105-10 (in English)

Banjong, D. N., Olson M. R. (2016). Issues and trends of international students in the United States. International Journal of Education, 4(1) (in English)

Ding, X. (2016). Exploring the experiences of international students in China. Journal of Studies in International Education, 20(4) (in English)

Nicholls, S. (2018). Influences on international student choice of study destination: evidence from the United States Journal of international students, 8(2), 597-622 (in English)

Number of international students. Retrieved from: https://www.statista.com/statistics/233880/internationalstudents-in-the-us-by-country-of-origin/ (in English)

Kasych, A., Vochozka, M. (2017). Conceptual provisions of development of Ukrainian national innovation system [Kontseptualni polozhennia rozvytku natsionalnoi innovatsiinoi systemy Ukrainy]. Naukovyi visnyk Polissia, 2(10), 16-23. Retrieved from: http://er.knutd.edu.ua/handle/123456789/7249 (in English)

Kasych, A. O., Tsygan, V. A. (2013). Osoblyvosti finansuvannya vyshchoyi osvity v Ukrayini ta inshykh krayinakh svitu [Features of financing higher education in Ukraine and other countries]. Efektyvna ekonomika, № 12. Retrieved from: http://www.economy.nauka.com.ua (in Ukrainian)

Munteanu, C., Munteanu, A. (2015). Education as a tool to enhance economic security. Retrieved from: http://www.cewse.pl/sites/default/files/materials/education_as_a_tool_to_enhance_economic_security_a._montenua.pdf (in English)

Kendiukhov, O. V. (2008). Efektyvne upravlinnia intelektualnym kapitalom [Effective management of intelligent capital]. Donetsk: DonUEP. (in Ukrainian)

Illiashenko, S. M. (2011). Intelektualnyi kapital VNZ yak zaporuka yoho innovatsiinoho rozvytku: sutnist, struktura, pidkhody do otsinky [HEI Intellectual Capital as a key to its innovation development: essence, structure, approaches to estimation]. Marketynh i menedzhment innovatsii, 1, 145-53 (in Ukrainian)

Sardak, S. E. (2016). Zhyttievyi tsykl sotsialno-ekonomichnykh system [The life cycle of social and economic systems]. Marketynh i menedzhment innovatsii, 1, 157-169. Retrieved from: http://mmi.fem.sumdu.edu.ua/ru/ journals/2016/1 (in Ukrainian)

Ranking of higher education institutions «TOP-200 Ukraine» [Reitynh VNZ «TOP-200 Ukraina»]. Retrieved from: http://www.euroosvita.net/reyt/ (in Ukrainian) 
Kaplan, R. S., Norton, D. P. (2005). The Balanced Scorecard - Measures that Drive Performance. Retrieved from: https://hbr.org/2005/07/the-balanced-scorecard-measures-that-drive-performance (in English)

Breus, S. V., Khaustova, Y. B., Denysenko, M. P. (2017). Zbalansovana systema pokaznykiv: formuvannia $\mathrm{z}$ perspektyvoiu zabezpechennia ekonomichnoi bezpeky vyshchykh navchalnykh zakladiv [Balanced scorecard: formation with perspective to ensure economic security of higher educational institutions]. Naukovyi visnyk Polissia, 4(12), 104-109. Retrieved from: https://er.knutd.edu.ua/bitstream/123456789/8848 (in English)

Breus, S. V. (2018). Rozroblennia modeli otsiniuvannia ekonomichnoi bezpeky zakladiv vyshchoi osvity [Development of evaluation model of economic security institutions of higher education]. Zbirnyk «Finansovokredytna diialnist: problemy teorii ta praktyky», 2(25), 176-182. Retrieved from: http://fkd.org.ua/article/ view/136355/ (in English)

Natsionalnyi instytut stratehichnykh doslidzhen (2013). [National Institute for Strategic Studies]. Shchodo vdoskonalennia metodolohii intehralnoho otsiniuvannia rivnia ekonomichnoi bezpeky Ukrainy. Analitychna zapyska. Retrieved from: http://www.niss.gov.ua/articles/1358/ (in Ukrainian)

Ministerstvo ekonomichnoho rozvytku i torhivli Ukrainy (2013). Metodychni rekomendatsii shchodo rozrakhunku rivnia ekonomichnoi bezpeky Ukrainy [Ministry of Economic Development and Trade of Ukraine. Methodical recommendations for calculating the level of economic security of Ukraine]. Retrieved from: http://www.me.gov.ua/ Documents/List?lang=uk-UA\&tag=MetodichniRekomendatsii (in Ukrainian)

Derzhavnyi komitet statystyky Ukrainy (2003). Pro zatverdzhennia Metodyky rozrakhunku intehralnykh rehionalnykh indeksiv ekonomichnoho rozvytku [State Statistics Committee of Ukraine. On approval of Methodology for calculating integral regional indices of economic development]. Retrieved from: http://uazakon.com/ documents/date_1a/pg_ibcnog/index.htm (in Ukrainian) 